\title{
Intention to Create Legal Relations and the Reform of Contract Law: A Conservative Approach in the Modern Global Era
}

\author{
Zhixiong Liao \\ Faculty of Law, University of Waikato, Hamilton, New Zealand \\ Email: zliao@waikato.ac.nz
}

Received March $5^{\text {th }}$, 2013; revised April 6 $6^{\text {th }}$, 2013; accepted April 14 ${ }^{\text {th }}, 2013$

\begin{abstract}
Copyright (c) 2013 Zhixiong Liao. This is an open access article distributed under the Creative Commons Attribution License, which permits unrestricted use, distribution, and reproduction in any medium, provided the original work is properly cited.
\end{abstract}

\begin{abstract}
This paper is partially to refute the submissions by Gulati's article recently published on Beijing Law Review which proposes abandoning the requirement of proving intention to create legal relations for the formation of an enforceable contract. After a critical analysis of the abandonists' arguments, this paper argues that intention to create legal relations is the "marrow of contractual relationships" and the arguments for abandoning such a requirement because of the existence of consideration and/or offer and acceptance as test(s) of contractual enforceability is untenable and unconvincing. Consideration and/or offer and acceptance may be evidence of serious intention to be bound somehow but unnecessary intention to be bound legally. For a number of reasons, the doctrine of consideration is very unlikely to work any better than the intention to create legal relations test. If a test of contractual enforceability must be abandoned, that should be the doctrine of consideration rather than the intention to create legal relations. This paper compares the current positions of some common law jurisdictions, upholds the needs of stability, consistency, and the harmonisation of contract law in the modern global era, and proposes a conservative approach of contract law reform regarding the intention requirement and the related presumptions, that is, all common law jurisdictions should "go back" to the orthodox English position.
\end{abstract}

Keywords: Intention to Create Legal Relations; Consideration; Contract Theory; Contract Law

\section{Introduction}

Recently, Beijing Law Review published an article written by Bhawna Gulati, entitled “"Intention to Create Legal Relations': A Contractual Necessity or an Illusory Concept” (Gulati, 2011). Gulati suggests that "intention to create legal relations" is not a contractual necessity but an illusory concept and "strongly argues for abandoning the requirement of proving an 'intention to create legal relation' in case of countries that require the existence of 'consideration' for forming a valid and enforceable contract” (ibid, p. 132).

Gulati (2011) raises again the interesting issue whether the "intention to create legal relations" should be a separate requirement, additional to agreement (offer and acceptance) and consideration, for the formation of a legally enforceable contract. The word "again" is used here because there has been a long-lasting debate on this issue and the argument for abandoning the requirement of (proving) intention to create legal relations (or intent to contract or contractual intention) is not new (Williston, 1957; Hepple, 1970).

For the convenience of discussion, this paper labels "abandonists" those who argue for or propose abandoning the "intention to create legal relations" as a requirement for the formation of a contract. This paper will critically analyse the abandonists' arguments. Contrary to the abandonists' view, this paper argues that intention to create legal relations is not an illusory concept but a necessity for the formation of a legally enforceable contract; and that consideration and/or offer and acceptance are not substitutes for such an intention requirement. If something must be exiled from common law, than that should be consideration rather than intention to create legal relations. This paper will also compare the current positions, regarding this issue, of some common law jurisdictions, namely, the United Kingdom (England), the United States, Australia and New Zealand. They seem to represent three different types of treatment of the intention to create legal relations and the related presumptions; and any of other common law jurisdictions seem to adopt one of these three positions. On the bases of the critical analysis and the comparison, and taking into account the need of harmonisation and unification of contract law in the modern "global era", this paper proposes a conservative approach of contract law reform regarding the intention to create legal relations requirement, that is, common law jurisdictions should "go back" to the orthodox position of English law.

\section{A Critical Analysis of the Abandonists' Arguments}

It is uncontroversial that courts should not enforce all agreements/promises made. The law must devise test(s) to distinguish enforceable contracts from unenforceable agreements/ promises. Many contract law doctrines/principles/rules are potentially capable of playing this "distinguishing role". Leaving aside those concerning "formality", "vitiating factors" and contract interpretation, the doctrines of offer and acceptance, consideration and intention to create legal relations are most rele- 
vant, regarding the formation of an enforceable contract. In the past decades, various arguments have been raised against the intention to create legal relations requirement. It is worthwhile to undertake a critical analysis of the abandonists' arguments in order to draw a plausible and convincing conclusion on this important contract law issue.

\section{Consideration and Intention to Create Legal Relations}

The most often raised and seemingly strongest argument for abandoning the intention to create legal relations requirement for the formation of an enforceable contract is that there already exists the doctrine of consideration as a test of legal enforceability hence the intention test is superfluous and unnecessary (Williston, 1957). This argument alone is insufficient to prove the redundancy of the intention to create legal relations requirement (intention test). A counter argument can equally be raised: the doctrine of consideration is unnecessary because there already exists another test of legal enforceability-the intention to create legal relations (Chloros, 1968). For the argument that the intention test should be abandoned to be convincing, at least such points must be proved: 1 ) the doctrine of consideration is sufficient to cover the functions of the intention test; and either 2) the doctrine of consideration is necessary for contract law or for an enforceable contract so it cannot be abolished, or 3) the doctrine of consideration (consideration test) works better than the intention test. Research finds, however, this is an extremely tough or impossible task for the abandonists.

\section{Is the Doctrine of Consideration Sufficient to Cover the Functions of the Intention Test?}

It has been noted that "the courts and the writers are unanimous that proof of serious intention is required" (ibid, p. 140) for an agreement to be enforceable. The essence of the intention test is that for an agreement to be enforceable the parties must intend to be legally bound by the agreement. It is argued that "the consideration itself can be taken as a proof strong enough to indicate the presence of intention of forming a legally binding contract" so a separate requirement of (proving) intention to create legal relations is "superfluous” (Gulati, 2011: p. 132). This argument obviously overlooks the circumstances where consideration could be found but the agreement is still unenforceable due to the parties indicate, expressly or impliedly, that they do not intend to be legally bound by the agreement. Consideration may be said a strong evidence to indicate the presence of the parties' intention to be bound somehow, but unnecessarily to be bound legally. It is true that the existence of consideration very often indicates the parties' seriousness about undertaking some kind of obligation, but unnecessary a legal obligation (Kimel, 2003: p. 138). Consideration may indicate the parties' serious intention to be bound but unnecessarily the intention to be legally bound.

It is widely accepted that freedom of contract is a valuable and fundamental principle of contract law. Freedom from contract is a corollary of freedom of contract. People should be allowed to make a contract (which is legally enforceable), and should equally be allow to make an agreement that is not legally enforceable but relying on trust, fidelity, love, affection, confidence and/or close relationships between the parties and/or other moral and social norms. "Making a legally binding agree- ment should be voluntary” (ibid, p. 132).

It might be argued that exclusion of courts' jurisdiction is illegal so the parties' intention to exclude their agreement from being enforced by courts should not be upheld. There is a significant and substantial difference between exclusion of courts' jurisdiction and exclusion of the legal enforceability of an agreement. A party to an agreement with a clause that "this agreement is binding in honour only ... and should not have any legal effects" may still bring the case to a court arguing for the existence of a contract and plea the court to enforce the agreement, but the court is very unlikely to enforce the agreement because of the parties' manifest intention not to be legally bound.

Therefore, even if we accept that the existence of consideration (the test of bargain) is sufficient to prove the parties serious intention, consideration is still insufficient to cover the essential function (let alone all the functions) of the intention to create legal relations test. A serious intention is unnecessarily an intention to be legally bound.

\section{Is Consideration Necessary for Contract Law or an Enforceable Contract?}

If the parties' intention to be legally bound itself is required for an enforceable contract, in order to argue that consideration is necessary for an enforceable contract, it must be proved that consideration is necessary for the proving of such intention. Consideration is not necessary for the purpose of proving intention to be legally bound. Consideration is even unnecessary for proving serious intention. There are many other ways to prove the parties' serious intention and/or intention to be legally bound. It is undeniable that a deed may be legally enforceable even if there is no consideration. It is also undeniable that contract law in civil law systems functions well despite the lack of the concept of consideration. It is a mistaken brief that the concept of "cause" in continental contract law "equivalents" or "corresponds" to the common law concepts of "consideration" (Chloros, 1968: pp. 145-147). These suggest consideration is unnecessary for the enforcement of some agreements. It has been suggested that consideration is a substitute of formality, which also functions to indicate the parties' serious intention. The key point is, therefore, enforceability of an agreement depends on whether the parties has by their statements or conducts shown their intention to be legally bound by the agreement. There are a number of methods to signify their serious intention or intention to be legally bound: inserting a clause that "this agreement is legally binding", employing a lawyer in the negotiation and/or drafting, adopting a formality (a deed, a notary public, an oath or to put the agreement in writing and $\operatorname{sign}^{1}$ ), performance immediately following the agreement, and etc. A nominal consideration deliberately taken by the parties may be stronger evidence than a substantial consideration to prove intention to be legally bound. All of these suggest that it is the parties' intention to be legally bound rather than the existence of consideration that is paramount for the enforcement of an agreement or a promise and that consideration is not neces-

\footnotetext{
${ }^{1}$ For example, the Judicature Act 1908 (NZ), s 92 provides that an acknowledgement in writing and signed by a creditor of the receipt of a part of his debt in satisfaction of the whole debt shall be enforceable notwithstanding "any rule of law". Here, the most relevant rule of law is that a (promise of) part payment of an existing due debt in satisfaction of the whole debt is unenforceable because of the lack of consideration, established by the House of Lords in Foakes v Beer (1884) 9 App Cas 605.
} 
sary for proving such intention².

Whether the doctrine of consideration is necessary for contract law is a highly controversial issue. Because this paper has argued that consideration is insufficient to cover all the functions of the intention test, and such sufficiency is essential for the validity of the argument that the intention test should be abandoned due to the existence of the consideration test, it is unnecessary to answer this controversial issue. For the purpose of this paper, it is sufficient to say that the consideration may indicate serious intention to be bound somehow but unnecessary the intention to be legally bound. Notwithstanding this, the following paragraphs are still helpful to show that the necessity of consideration for contract law has been seriously doubted.

Professor Coote points out that "the idea that consideration is essential to the very notion of a contract is a typical common law concept, but it is quite untrue" and "if it were true, common law countries would be the only ones which knew what a contract was" (Coote, 1995: p. 22). In fact, "[t]he civil law systems have been able to develop a perfectly adequate law of contract without consideration” (Chloros, 1968: p. 164). It has been argued that consideration is "neither a necessary nor a central feature of contractual obligation" whether contractual obligetion is reliance-based or voluntary assumption based (Benson, 2001: p. 121). If contractual liability is only one form of reliance-based promissory obligations, as what Atiyah (1986: pp. 40-42) argues, then "consideration becomes evidence of reliance, nothing more” (Benson, 2001: p. 121). "It is the existence of reliance that is the crucial factor in establishing liability, whether or not consideration has been given" (ibid). If contractual liability is to be understood not reliance-based, but as voluntary or intentional assumption of promissory obligation, as what Fried (1981: pp. 28-39) and Coote (2010: pp. 7-51) argue, then such voluntary assumption "need not depend upon or be evidenced by the existence of consideration" (Benson, 2001: pp. 121).

\section{Does the Consideration Test Work Better than the Intention Test?}

Simply saying that there is another test (the consideration test) of enforceability is not sufficient to prove that the intention test should be abandoned. It must also be proved that why this (intention) test, rather than that (consideration) test, should be abandoned. In this regard, this paper argues that the consideration test is very unlikely to work any better than the intention test and if one of these two tests must be abandoned it should be the consideration test rather than the intention test. Firstly, the doctrine of consideration suffers not less attacks by scholars than the intention test. It has been noted that all of the doctrines of offer and acceptance, consideration and intention to create legal relations suffer criticisms but the attacks on consideration are the most severe; and "it is unlikely that English law would adopt the doctrine of consideration were it to be given the opportunity to start afresh" (McKendrick, 2003: p. 273). "Many have found" the doctrine of consideration confusing (Coote,

\footnotetext{
${ }^{2}$ This can be illustrated by the United States Uniform Written Obligation Act (drafted by Williston and is adopted in Pennsylvania), s 1 , which proposes: "A written release or promise hereafter made and signed by the person releasing or promising shall not be invalid or unenforceable for lack of consideration, if the writing also contains an additional express statement, in any form of language, that the signer intends to be legally bound". See Uniform Written Obligations Act, s 1, in Handbook of the National Conference of Commissioners on Uniform State Laws and Proceedings 584 (1925), cited in Klass (2009: p. 1450).
}

1995: p. 22). Justifications claimed for the doctrine of consideration have been forcefully argued illusory and untenable (Koo, 2011).

Secondly, there have been official law reform proposals for abandoning the doctrine of consideration but there is none for abandoning the intention test. The United Kingdom Law Revision Committee's 1937 Report proposed a reform of some of the rules on consideration, such as writing as a substitute for consideration and moral obligation as good consideration (Chloros, 1968: p. 144). It is observed that "[I]n effect, the Report spelt the abolition of the doctrine through the back door" (ibid). Later in 1968, a paper commissioned by the United Kingdom Law Commission pointed out that the rest aspects of the doctrine of consideration "would have been modified by the Committee's other proposals, e.g., the proposal to abolish the rule that past consideration is no consideration" and "[h]ad these proposals been put into effect they would have resulted in the virtual abolition of the doctrine of consideration although in theory English law would have still been governed by that doctrine” (ibid). The 1968 paper, after detailed discussions, concluded that "English law would lose nothing if the doctrine of consideration were to be abolished" (ibid, p. 164).

Finally but most importantly, some severe problems with the doctrine of consideration have been recognised, and the possibility of abolishing the doctrine has been seriously discussed and considered, by courts in some common law jurisdictions. For example, as Professor Coote noted, in re Selectmove Ltd [1995] 1 WLR 474, “a differently constituted [English] Court of Appeal ... has found impossible to reconcile" the English Court of Appeal discussion in Williams $v$ Roffey Bros \& Nicholls (Contractors) Ltd [1990] 1 All ER 512 ${ }^{3}$ with the decision of the House of Lords in Foakes $v$ Beer (1884) 9 App Cas 605 (Coote, 1995: p. 22). Most notably, judges in the Singapore High Court and Court of Appeal, recently, in a number of case judgements, "openly questioned the utility of the doctrine [of consideration]” (Koo, 2011: p. 464). In Chwee Kin Keong v Digilandmall.com Pte Ltd [2004] 2 SLR(R) 594, Rajah JC (as he then was) of the Singapore High Court in obitor, strongly doubted the necessity of consideration in commercial contracts and upheld the intention test. His honour stated (at para. [139]):

The modern approach in contract law requires very little to find the existence of consideration. Indeed, in difficult cases, the courts in several common law jurisdictions have gone to extraordinary lengths to conjure up consideration. (See for example the approach in Williams $v$ Roffey Bros \& Nicholls (Contractors) Ltd. [1990] 1 All ER 512.) No modern authority was cited to me suggesting an intended commercial transaction of this nature could ever fail for want of consideration. Indeed, the time may have come for the common law to shed the pretence of searching for consideration to uphold commercial contracts. The marrow of contractual relationships should be the parties' intention to create a legal relationship [Emphasis original].

Another Judge, Phang J, in another Singapore High Court case of Sunny Metal \& Engineering Pte Ltd v Ng Khim Ming Eric [2007] 1 SLR(R) 853, also in obitor, extended the judicial criticism of the consideration doctrine to non-commercial transactions. His honour suggested that "the doctrine of considera-

\footnotetext{
${ }^{3}$ In this case, the English Court of Appeal invented the concept of "practical benefit" to get around the consideration requirement in order to achieve a just outcome.
} 
tion may be outmoded even outside the context of purely commercial transactions” (at para. [29]) because (at para. [30]):

[T] cholls (Contractors) Ltd. ... and the well-established proposition that consideration must be sufficient but need not be adequate [make it] all too easy to locate some element of consideration between contracting parties. This would render requirement of consideration otiose or redundant, at least for the most part.

Most recently in 2009, Phang JC (this time sitting as a Court of Appeal judge), in his judgement of the Singapore Court of Appeal case of Gay Choon Ing $v$ Loh Sze Tie Terrence Peter [2009] 2 SLR(R) 332, continued his attacks on the doctrine of consideration. After the conclusion of the judgment, he added a lengthy (11 pages) critique entitled "A coda on the doctrine of consideration” (at para. [92-118]), which discussed the history and rationale of, and difficulty, with the doctrine, and suggested that doctrines of economic duress, undue influence and unconscionability are possible alternatives of the doctrine of consideration (at para. [113]).

The above analysis shows that the problems with the doctrine of consideration have been recognised, and the possibility of abolishing the doctrine has been seriously considered and argued for, not only by academics, but also by official law reform reports and judicial opinions in some common law jurisdictions. This is, however, not the case regarding the intention to create legal relations requirement. This shows that the doctrine of consideration is very unlikely to work any better than the intention to create legal relation test.

Some might argue that in the United States intention to create legal relations is not required for a contract, because Section 21 of the Restatement (Second) of Contract provides that "[n]either real nor apparent intention that a promise be legally binding is essential to the formation of a contract”. Such an argument ignores the proviso of the Section 21 (Which provides "but a manifestation of intention that a promise shall not affect legal relations may prevent the formation of a contract"), the Comments to the section ${ }^{4}$ and the fact that the Restatement is only "black-letter rules" which does "not necessarily describe judicial practice” in the United States (Klass, 2009: p. 1448). Section 21 of the Restatement in effect merely indicates enforcement as a default with an opt-out rule and subject to exceptions where the proof of intention is required (ibid). It cannot be said that intention to contract has been abolished from the contract law of the United States. This issue will be discussed further in part III of this paper where the current position of the US law is analysed. Further, even some scholars who strongly argue for abandoning the intention requirement has noted that "US [.] and UK require the establishment of 'intention to create legal relations' in addition to the existence of 'consideration'” (Gulati, 2011: p. 127).

A few scholars have noted that "[c]ase authorities in many common law jurisdictions show that both animus contrahendi and consideration are prerequisites to contract" (Cheshire and Fifoot, 1969: p. 189). It should also be noted that the "case authorities" referred to are limited to those before 1970, far

${ }^{4}$ Restatement (Second) of Contracts s $21 \mathrm{cmt}$ c (1981) provides that "[i]n some situations the normal understanding is that no legal obligation arises, and some unusual manifestation of intention is necessary to create a contract. Traditional examples are social engagements and agreements within a family group". before the notable cases demonstrating the confusion and difficulties of the doctrine of consideration, such as Williams $v$ Roffey Bros \& Nicholls (Contractors) Ltd. [1990] 1 All ER 512, Re Selectmove Ltd. [1995] 1 WLR 474, and the recent Singapore cases discussed above. Importantly, these suggestions, whether true or not, at least do not point in favour the argument that the consideration test works better than the intention test hence it is the intention test rather than the consideration should be exiled from common law.

In summary, consideration is neither sufficient nor necessary in proving intention to create legal relations. The doctrine of consideration is under fierce attacks, both by academics and judicial opinions, and it is very unlikely to work any better than intention to create legal relations as a test of enforceability of agreements.

\section{“Intention to Create Legal Relations" and "Offer and Acceptance"}

It is also argued that intention to be legally bound "is already necessary" for the finding of offer and acceptance and to overcome any uncertainty, "each of which is already a constituent of an enforceable contract" so "intention to create legal relations as an additional requirement is superfluous" (Chen-Wishart, 2009: p. 444).

If this argument were correct, it would equally apply to consideration and would also make consideration redundant. If intention to be legally bound is already proved by the finding of "offer and acceptance" and "certainty", which are "already constituent[s] of an enforceable contract" (ibid, emphasis added), anything else including consideration would be superfluous, as the most often and seemingly strongest argument for abandoning the (proof of) intention requirement is "the consideration itself can be taken as a proof strong enough to indicate the presence of intention of forming a legally binding contract" (Gulati, 2011: p. 132). An absurd outcome would logically flow from the abandonists' argument, that is, so long as there are offer and acceptance and certainty, there will be an enforceable contract. A further nightmare for consideration will also naturally flow from this argument, that is, as Benson (2001: pp. 149-155) pointed out, an offer necessarily contains a promise by the offeror and the offeree's acceptance must also contain a promise in exchange for the offeror's promise. In that way, offeror's promise in exchange for offeree's promise (consideration) "is already necessary" for the finding of offer and acceptance and overcome any uncertainty, and "each of which is already a constituent of an enforceable contract” (Chen-Wishart, 2009: p. 444), hence a separate test of consideration is unnecessary.

A more appropriate view is that offer and acceptance (with certainty) alone is not enough for the formation of an enforceable contract. Offer and acceptance must be supplemented by other doctrines. Offer and acceptance (with certainty) focus on the phenomenon of consensus ad idem. Offer is an expression of the offor's willingness to be bound by the terms of the offer, but unnecessary with the intention to be legally bound. A contract can be deconstructed into three levels. First, offer and acceptance concludes an agreement, but whether the agreement is legally binding is another issue. Second, if the agreement is supported by consideration, the agreement is binding somehow but unnecessarily legally. Third, if there is intention to create legal relations, the agreement is legally binding and thus a con- 
tract.

Therefore, it is the intention to be bound somehow rather than the intention to be legally bound is "is already necessary" for the finding of offer and acceptance and to overcome any uncertainty. In this sense, the above problems raised are even more troublesome for consideration, because offer and acceptance have already required the parties' intention to be bound somehow by the promises made in exchange for each another. They are exactly what consideration functions in that the existence of consideration also indicates the parties' intention to be bound somehow. If something is superfluous for the formation of an enforceable contract that must be consideration rather than the intention to create legal relations.

It might also be argued that the seriousness of the parties' intention is already required for the finding of offer and acceptance, because an offer (acceptance) not seriously made is simply not an offer (acceptance) at all. This is true but similar to what this paper argues above in part II A, in making effective offer or acceptance, the offeror and offeree must show their seriousness about undertaking some kind of obligations, but unnecessarily seriousness about undertaking legal obligations. If an "offer" was not seriously made, the maker "did not express an intention to create any relations, legal or otherwise" (Smith, 2005: p. 37, emphasis original). Merely serious intention to be bound is not enough for a legally enforceable contract, there must be serious intention to be legally bound. Again, if something must be abandoned, that will be consideration rather than the intention to create legal relations, because consideration only indicates the parties serious intention (not necessarily legal intention) and such seriousness "is already necessary" for the finding of offer and acceptance and to overcome any uncertainty, "each of which is already a constituent of an enforceable contract” (Chen-Wishart, 2009: p. 444).

\section{The Domestic/Commercial Distinction}

Another way of arguing for abandoning the requirement of (proving) of the intention to create legal relations is to attack the two rebuttable presumptions based on the distinction between domestic/social and commercial agreements: "that commercial agreements are prima facie enforceable and social and domestic agreements are not” (ibid). Three sorts of arguments were put forth in support the suggestion that presumptions based the domestic/commercial agreements distinction "are no longer reasonable and justifiable” (Gulati, 2011: p. 129).

Despite the attacks on the distinction between domestic/social and commercial agreements, the courts in most common law jurisdiction still treat them differently. Pure domestic agreements are classic examples of non-commercial agreements. Other non-commercial agreements may include "appointment" agreements between a church and a priest (as that in Ermogenous v Greek Orthodox Community of SA Inc [2002] HCA 8), a collective agreement between a labour union and an employer (as that in Ford Motor Co Ltd v Amalgamated Union of Engineering and Foundry Worker [1969] 1 WLR 339). Courts very often treat them by referring to domestic/social agreements. For the convenience of analysis, this paper uses domestic agreements as an illustration of how non-commercial agreements are and should be treated.

\section{The Changing Appearance versus Nature of Domestic/Social Relations}

It is argue that due to "the changing nature of domestic/so- cial relations", "the dividing line between the domestic and commercial contracts is shrinking”, so the presumptions based on the domestic/commercial agreements distinction "is no longer reasonable and justifiable” (Gulati, 2011: p. 129). Criticisms can be made on this argument. First, this argument mixes up the appearance of domestic/social relations with the nature of such relations. It must be noted that the nature of domestic/ social relations has not substantially changed notwithstanding that the appearance of such relations seems to have changed. "[H]igh divorce rates" and "more precise statements about a couple's obligations" (ibid) do not mean nowadays the nature of the relation between husband and wife is not dissimilar to a commercial relation. Who is able to forcefully argue that today the nature of domestic relations is basically commercial? Even if there are some "commercial factors" in the domestic relations, it is undeniable that "love, honour and cherish" are still the nature of familial relations. In commercial settings, agreements are generally results of "at-arms-length bargaining" whereas in domestic settings it is very much more likely (than in comercial settings) that agreements are results of generosity/good will/care/passion and love. "Family agreements differ categorically from arms-length commercial contracts” (Trebilcock \& Elliott, 2001: p. 53). Had the nature of familial relations substantially changed and become not dissimilar to commercial relations, family as the basic structure of our society would have disappeared.

It might be true that husbands and wives "often have divergent interests” (ibid, p. 60), but this does not mean the basic nature of the relation between husbands and wives are substantially the same with commercial relations between strangers or business partners. "Whereas commercial actors can be assumed [...] to be actuated by self-oriented motives, family members cannot be" (ibid, p. 53). "Family financial arrangements should not [...] be thought of as bargains in the strict sense" (ibid). When courts apply generic contract law principles/rules on agreements between husbands and wives, such divergent interests might "not always be appreciated" (ibid, p. 60, emphasis added), but principles/rules of other areas of law (such as family law) may step in to fill the gap where such divergent interests should be appreciated to achieve just and fairness. That fact that legislation requires much more stringent formality for certain agreements between husbands and wives to be legally enforceable ${ }^{5}$ demonstrates the special nature of familial relations and that there are substantial differences between domestic and commercial arrangements. Such legislation also reflects the fact that close relationships may often affect the parties' judgments as to the nature, value and terms of the agreements hence courts should be more cautious about enforcement of agreements between parties with domestic/social relations.

Second, the abandonists' argument mixes up domestic agreements with domestic contracts. "The dividing line between the domestic and commercial contracts is shrinking” (Gulati, 2011: p. 129, emphasis added) does not mean the distinction between

${ }^{5}$ This can be illustrated by the Property (Relationships) Act 1976 (New Zealand), section 21, which provides that for an agreement dealing with relational property between a couple (whether married, civil union or de facto partners) to be legally enforceable, such agreement must be in writing, signed by each party in the presence of a lawyer who must certify that independent legal advice has been given regarding the implications and effects of the agreement. Similarly in Australia, the Family Law Act 1975 (Cth), sections 90B-90G set out stringent requirements for the enforcement of financial agreement between spouses, including the agreement being in writing, signed, independent legal advice, etc. 
domestic and commercial agreements or arrangements no longer exists. For contracts, whether domestic or commercial, the distinction should be very limited. However, a large amount of domestic/social agreements or arrangements are not contracts, the distinction between domestic/social and commercial agreements are still substantial. Further, assuming what is argued were the "dividing line between the domestic and commercial agreement is shrinking", such an argument would still fail to spell out to what extent "the dividing line" must be "shrinking" in order to justify treating domestic/social agreements the same way as commercial agreements.

Third, most importantly, this abandonists' argument ignores the fact that the distinction of the underlying values promoted by the different categories of arrangements remains unchanged. The fundamental distinction between domestic/social and commercial arrangements still exists for the purpose of contract law. Generally, domestic/social arrangements "are not bargains in the ordinary sense of the term" and parties enter into domestic/social agreements mainly for the purpose of promotion of the parties "shared interest" [emphasis original] whereas commercial agreements are generally bargains whereby the parties pursue personal advantages, that is, self-interest of a party (Smith, 2004: p. 214). The shared interest "lies both in the subject matter of the agreement (children, housework, etc.) and in the goal of strengthening the relationship itself" (ibid). The law should uphold rather than undermine the distinctive "sharedinterest" value of families and/or other close social relations. The proper way of upholding is non-interference, that is, to leave domestic/social arrangements in the hands of the parties, because "the mere threat of legal enforcement can change the character, and hence the value, of domestic agreements" (ibid). This may be an important justification for the non-enforcement default of domestic/social agreement.

\section{Relational Contract and Behavioural Decision Theories}

It is argued that the application of behavioural decision theory "undermines the distinction between family and comercial arrangements” (Keyes \& Burns, 2002: p. 588) and that relational theory "suggests that the similarities between the two categories may outweigh the differences” (ibid, p. 586), hence, family agreements should be presumed to be enforceable as commercial ones (ibid).

Relation contract theory argues that the majority of contractual arrangements are relational contracts, the parties to which value and endeavour to preserve relations and uphold social norms rather than simply attempt to maximise wealth or efficiency (Seddon \& Ellinghaus, 1997: pp. 894-896). The parties value incompleteness and the flexibility coming from incomepleteness (Heffey, Paterson, \& Robertson, 2002: p. 27). They "seek to preserve their business relationships where possible, rather than to enforce their contractual rights” (keyes \& Burns, 2002: p. 586). Therefore, it is argued, that "when commercial contractual relationships are viewed in this way, there is little justification for the distinction between family and commercial arrangements...” (ibid).

This argument is not without problems. First, relational contract theory has its drawbacks. Not all commercial relations are long term and on-going relations and many contracts are entered into for one-shot transactions only. Furthermore, it would be incorrect to treat all relational contracts as one category, and contracts can be relational in various senses and to various degrees (Heffey, Paterson, \& Robertson, 2002: p. 28). Some busi- nesses, such as franchising, joint venture, and the supply chain of processing materials may be relational; whereas others such as the commercial banking industry may be less relational (ibid)

Second, even if all or most commercial contract were relational, there would still be substantial difference of the underlying values between commercial relational contracts and familial agreements. Parties to commercial relational contracts may put down the short-term self-interest temporarily in order to preserve the longer business relationships, but the rival self-interest of each party still exists for a long run. It is unimaginable that commercial parties value the relations to such an extent that they ignore both the short-term and long-term self-interest. Business organisations may uphold or be required to follow social norms, but this does not mean the pursuing of profit (including long-term business gains or business advantages) is no longer an important objective of business organisations. The basic function and objective of commercial relations, no matter how relational they may be, is still substantially different from those of domestic/social relations. Commercial contracts, including the relational ones, are still a basic mechanism for the parties' to deal with each another at arm's length, whereas domestic/social agreements are not.

Third, the meaning and effect of "incompleteness", a striking feature of relational contracts, are different for relational commercial contracts and domestic/social agreements. For commercial agreements, the gaps as a result of the "incompleteness" can be filled, for "business efficacy", by implied terms developed based on commercial practices in a particular market sector, the context of "a contractual community" (Wightman, 2000: p. 106), so the "incompleteness" may not be a real one in many circumstances. For domestic/social agreements, however, "the parties are not participating in practices which share a set of norms which commonly apply to a category of situations" (ibid, p. 107), no "sector wide" practices can be adopted to fill the gaps, so the "incompleteness" in domestic/social agreements are much more substantial and real.

Behavioural decision theory (BDT) "suggests that human beings, whether involved in family or commercial arrangements, are affected by numerous irrational decision-making processes. These may affect the ability to make a rational choice at the outset about whether an arrangement should be contractually binding” (Keyes \& Burns, 2002: p. 588). It is therefore argued that the application of behavioural decision theory "undermines the distinction between family and commercial arrangements" (ibid).

Three points can be made about this argument. First, the theoretical validity of BDT remains to be seen. Posner comprehensively criticised BDT's attacks on rational choice theory (Posner, 1998). Second, even if BDT itself is theoretically tenable, it may not be appropriate to apply in analysing legal issues. Many scholars have argued that the BDT, primarily based on cognitive and social phycology, is not appropriate to apply in analysing legal issues (Hillman, 2000; Rostain, 2000). Third, even if BDT could be apply in analysing legal issues BDT would not necessarily "undermines the distinction between family and commercial arrangements” (Keyes \& Burns, 2002: p. 588) to such an extent that substantially vitiates the distinction. If "rationality" means self-interested, wealth-maximising as an "economic person" is presumed to pursue, in domestic arrangement settings, the parties are much more likely to be "irrational" in decision making than parties in commercial tran- 
sactions. Close relations between the parties inevitably influence their cognitive and psychological aspects which impair the ability/mood/environment for a rational decision making. The closer the relations between the parties are, the more likely the parties may make "irrational" decisions and the more severe the "irrationality" may be. Even if both family members in domestic agreements and parties in commercial transactions are "irrational", their degrees of "irrationality" could still be so substantially different that it is inappropriate for contract law to treat the two categories of agreements in a same way.

\section{Difficulty of Distinguishing Domestic/Social from Commercial Agreements}

It is argued that determining the category of the agreement in issue is a prerequisite for the courts to choose an appropriate presumption of the parties' intention, but it could be extremely difficult to determine whether a particular agreement is a domestic/social one or a commercial one in certain circumstances, especially, where the two types of relations are intermingled, such as a family business (Gulati, 2011).

Admittedly, in practice it could be very difficult to distinguish domestic/social relations from commercial settings in certain circumstances, especially, in "intermingle” cases. In this regard, courts have developed rules/principles that are helpful in dealing with borderline or intermingled cases. For example, a business agreement between family members would be treated as a commercial agreement and the intention to be legally bound is thus presumed; or if it is treated as a domestic agreement the "no intention" presumption will be rebutted by the commercial aspects (as in Roufos $v$ Brewster (1971) 2 SASR 218). "An ordinary commercial contract or contract of employment is not rendered unenforceable by the mere fact that the parties happen to be closely related" (Lucke, 1967-1970, p. 424). The "no intention" presumption does not apply to estranged couples, or the presumption is rebutted by the fact of the estrangement (Merritt v Merritt [1970] 1 WLR 1211). Over time, courts have identified factors pointing in favour or against the finding of intention to be legally bound ${ }^{6}$, which could also be helpful in determining the nature of the relationships and the application and rebuttal of the presumptions.

Most importantly, the practical difficulty does not negate the clear distinction of different values promoted by the different types of agreements. Practical difficulty does not justify treating the same way the two types of agreements which are substantially different in nature. Such practical difficulty is not unique to contract law. Many other areas of law have similar practical difficulties, which may be even worse than the distinguishing domestic/commercial relations. For example, in tax law, it could be extremely difficult to determine whether a particular sum spent/received is revenue or capital in nature, or whether a tax payer's conducts amounts to tax avoidance or merely tax mitigation. The difficulty does not result in courts treating revenue and capital, tax avoidance and tax mitigation in the same way. This is because revenue and capital, tax avoidance and tax mitigation are completely different in nature which justifies courts to treat them completely differently, despite the practical difficulty.

In summary, although the society has been changed over the 90 more years after the judgment of Balfour v Balfour [1919] 2 KB 571, the fundamental distinction, that is, the different val-

${ }^{6}$ For case authorities and discussions on this, see Lucke (1967-1970: pp. 421-422). ues promoted by domestic/social and commercial arranges, remains unchanged. Neither relational contract theories and behavioural decision theory, nor practical difficulty in distinguishing domestic arrangements form commercial arrangements negates the underlying value and nature distinction between domestic and commercial arrangements. Such a distinction still exists and will continue to exist no matter how the society develops and changes so long as the nature and value of domestic and other close relations based on love, passion, affection, trust or other moral or social norms are still appreciated by human beings. It is another issue whether courts should continue to adopt different evidentiary presumptions for proving intentions to create legal relations in different settings. This will be discussed in the law reform part of this paper.

It should also be noted that even if it were successfully argued that the presumptions based on the domestic/commercial distinction should be abandoned, the displacement of the presumption would still not mean the proving of the intention to create legal relations should not be a requirement for the formation of an enforceable contract. The requirement of proving is one thing, whether applying presumptions in the proving process is another thing.

\section{“Legal Fiction”, “Difficult to Prove” and "Manipulation"}

It is argued that "the orthodox language of intention appears to be based on a legal fiction, in that few (if any) parties turn their minds at the time of forming such agreements to the question of whether legal rights are being created" (Poole, 2006: p. 189). Since intention is a subjective state of mind, which is "notoriously difficult to prove", "there is often no objective evidence which may be produced as conclusive proof" (ibid, p. 186). Therefore, courts may manipulate the intention test (or the presumptions) for "the appropriateness of enforcement in the particular contexts" (Chen-Wishart, 2009: p. 444).

The problems raised above are related not only to the proving of intention to create legal relations, but also to the intention itself; and some problems are related to any kinds of intention. Unless the concept of intention (not limited to contractual intention) is excluded from contract law, these problems will remain. It has been noted, however, that "the courts and the writers are unanimous that proof of serious intention is required" (Chloros, 1968: p. 140, emphasis added). There is a dilemma for those who argue for abandoning the intention test: if they accept that serious intention is unnecessarily legal intention, this paper thanks them for backing up the argument that consideration, offer and acceptance may indicate serious intention but unnecessarily legal intention; but if they argue that serious intention means intention to create legal relations, then any attacks on the intention to create legal relations requirement, including the "legal fiction", "difficult to prove" and "manipulation", will be attacks on their own arguments. It seems that they do not mean that serious intention or intention to be legally bound is unnecessary but that the proving of such intention is redundant because "the consideration itself can be taken as a proof strong enough to indicate the presence of intention of forming a legally binding contract” (Gulati, 2011: p. 132). The difference between arguments for and against the intention test is not whether the intention itself is required, but whether a separate intention test is necessary additional to the consideration test for enforceability. Therefore, the arguments that con- 
sideration, offer and acceptance should be taken as evidence strong enough to prove the intention to be legally bound is based on the same ground that such intention itself is still required. Consequently, a difficulty for one argument is equally a difficulty for the opposite. So long as the notion of "serious intention" is still relied upon by contract law for the purpose of distinguishing contracts from unenforceable agreements, the above raised problems with intention will go with arguments for both sides.

Particularly, as to the difficulty of proving intention and the intention objectively proved may be different from what the parties actually intended, the proving of consideration has the same difficulty, because "promises can only be made intentionally" and the search for intention is necessarily subjective (Smith, 2004: p. 174). As an offer is an expression of the offeror's intention to be bound by the terms of the offer, the existence of an offer hinges on the intention, which is again subjective. This problem goes to the fundamental objective theory of contract. It is settled law that intention can only be inferred from objective facts. In determining the parties' intention, courts look at the statements and conducts of the parties rather than their internal state of mind. Interestingly, having said that "there is often no objective evidence which may be produced as conclusive proof” (Poole, 2006: p. 186), how can abandonists argue that "the consideration itself can be taken as a proof strong enough to indicate the presence of intention of forming a legally binding contract” (Gulati, 2011: p. 132, emphasis added)? Is consideration an exception or not objective evidence at all?

Similarly, the manipulation concern is not unique to the intention test. Even if the intention requirement is abolished, there is still the concern that courts may manipulate the doctrine of consideration or other contractual requirements to achieve "the appropriateness of enforcement in the particular contexts" (Chen-Wishart, 2009: p. 444). The invention of "practical benefit”, in Williams $v$ Roffey Bros \& Nicholls (Contractors) Ltd [1990] 1 All ER 512, as consideration is a good illustration of such possible manipulations. The manipulation concern will not be alleviated by abandoning the intention requirement. Any judicial discretion could be a risk of judicial manipulation. Flexibility is inevitably at the price of certainty, but the excessive pursuit of certainty may result in rigidity. Manipulation can be minimized by a set of consistent principles and the doctrine of precedents. In this sense, keeping the two rebuttable presumptions of intention base on domestic/social and commercial distinction may be a good way to balance the competing needs of flexibility and certainty.

\section{Comparison of Current Positions in Common Law Jurisdictions}

\section{Current Positions in Some Common Law Jurisdictions}

The current positions in the United States, United Kingdom (England), and Australia/New Zealand represent three categories of positions adopted by common law jurisdictions concerning the requirement of intention to create legal relations and the related evidentiary rules. Arguably, any of the other common law jurisdictions currently adopts one of these three positions. It is therefore helpful to have a comparison of them before law reform proposals are made.
In the United States, section 21 of the Second Restatement of Contracts provides that "Neither real nor apparent intention that a promise be legally binding is essential to the formation of a contract, but a manifestation of intention that a promise shall not affect legal relations may prevent the formation of a contract”. The comments to Section 21, however, provide that "[i]n some situations the normal understanding is that no legal obligation arises, and some unusual manifestation of intention is necessary to create a contract. Traditional examples are social engagements and agreements within a family group" (Restatement (Second) of Contracts, s 21 cmt c (1981)). This means that the United States contract law has not abandoned the notion of intention to create legal relations but merely adopted enforcement as a default with exceptions of non-enforcement. One exception is where the parties' intention not to be legally bound is manifested (the second clause of the Restatement (Second) of Contracts, s 21). Another is that "[i]n some situations" (including situations where domestic or social agreements are involved) intention to create legal relations "is necessary to create a contract” (Restatement (Second) of Contracts, s $21 \mathrm{cmt} \mathrm{c} \mathrm{(1981)).}$

The orthodox and current position of English law is that intention to create legal relations is necessary, additional to consideration, offer and acceptance, for the formation of a legally enforceable contract (This is confirmed in Baird Textile Holdings Ltd v Marks \& Spencer plc [2001] EWCA (Civ) 274 at [59]). There are also two established rebuttable presumptions. One is that commercial agreements are presumed to be legally binding unless courts are satisfied by strong evidence to the contrary (Edwards v Skyways Ltd [1964] WLR 349; O'Keefe v Ryannair Holdings plc [2002] IEHC 154). The other is domestic/social agreements are presumed not to be legally binding unless proved otherwise by evidence to the contrary (Balfour $v$ Balfour [1919] 2 KB 571; Jones v Padavatton [1969] 2 All ER $616)$.

Traditionally, Australian and New Zealand law took the same position as that in English law but this has been changed by judicial actions. Currently in both Australian and New Zealand law, intention to create legal relations is required and the party alleging the existence of the contract is to prove the existence of the intention. The two rebuttable presumptions based on the domestic/commercial distinction have been doubted by the Court of Appeal of New Zealand in Fleeming $v$ Beevers [1994] 1 NZLR 385, and by the High Court of Australia in Ermogenous v Greek Orthodox Community of SA Inc [2002] HCA 8. It is suggested that the effect of these case judgements is that the presumptions of intention (or no intention) to be legally bound are no longer relied upon in any context (Burrow, Finn \& Todd, 2012: p. 172; Courmadias, 2006: pp. 175-185). As the intention to create legal relations is still required for an enforceable contract and the presumptions are no longer relied upon, the general rule of evidence concerning the burden of proof applies, which means an agreement will not be enforceable unless the party alleging the existence of a contract proves the intention to create legal relations.

\section{Comparison of the Current Positions}

It has been observed that concerning enforceability of contracts and intention to create legal relations the real difference between English law and US law is not as what the "black letter” rules indicate (Klass, 2009: pp. 1438-1439). The actual 
situation is that courts in both jurisdictions presume, in practice, that commercial agreements are enforceable and domestic agreements are not. In the United States, the law provides intention to be legally bound is generally not required and commercial agreements are enforceable as a default, unless there is manifest intention of the parties not to be legally bound (Restatement (Second) of Contract, s 21). English law says that intention to create legal relations is required, but courts presume the existence of such intention unless satisfied by strong evidence to the contrary (Edwards $v$ Skyways [1964] 1 WLR 349; Rose and Frank Co v J R Crompton \& Bros Ltd [1932] 2 $\mathrm{KB}$ 261). The effect is that commercial agreements are enforceable as a default. Therefore, although there seems to be a huge difference between the "black letter" law of United States (which says intention to be legally bound is not required) and that in England (which says intention to be legally bound is required, as stated in Baird Textile Holdings Ltd v Marks \& Spencer plc [2001] EWCA (Civ) 274 at [59]), the real practice is that commercial agreements in both jurisdictions are enforceable as default. The minor difference is that in the United States, an otherwise enforceable commercial agreement will not be enforced only if the parties manifest (express) their intention not to be legally bound (Klass, 2009: pp. 1468-1469), whereas in England, an otherwise enforceable commercial agreement will not be enforced if there is strong evidence (very often but unnecessarily being express statements of the parties) of the parties' intention not to be legally bound (Edwards $v$ Skyways Ltd [1964] WLR 349). Despite this difference, the English law, by adoption of the strong presumption and other evidentiary rules (such as reading ambiguous expression of intent against the defendant, holding one-sided or partial performance of the agreement negates an unambiguous statement that it is not intended as a contract), "produces the same outcome" as the United States law would "in most commercial cases" (Klass, 2009: p. 1459).

As to non-commercial agreements, especially domestic/social agreements, the United States' law and the English law, regarding intention to contract, are even more similar. Intention to create legal relations is required for domestic and social agreements to be enforceable in both jurisdictions. In the United States, "the normal understanding is that no legal obligation arises, and some unusual manifestation of intention is necessary to create a contract" (Restatement (Second) of Contracts, 21 cmt c (1981)). Here, "the normal understanding” corresponds to the English law presumption that domestic/social agreements are prima facie unenforceable, and the "manifestation of intention is necessary to create a contract" corresponds to the English rule that the non-enforcement presumption can be rebutted by evidence to the contrary.

Both English law and the law in Australia/New Zealand require intention to create legal relations for the formation of an enforceable contract, but the English law adopts the two evidentiary presumptions whereas the law in Australia/New Zealand seems have abandoned such presumptions. The effect of abandoning the presumptions is that intention to create legal relations as a contractual requirement is to be proved by the party arguing for enforcement of the agreement in issue, whether it is a commercial agreement or not. For domestic/ social agreements, this does not, in practice, change the nonenforcement default, in that whether the presumption is adopted or not, such agreements are prima facie unenforceable unless intention to create legal relations is proved. For commercial agreements, the difference seems to be more obvious, at least when the "black letter" rules are concerned. As English law adopts the strong presumption that parties to commercial agreements are intended to be legally bound, commercial agreements are prima facie enforceable. Positive proof of the intention to be legally bound is not required. Whereas in Australia and New Zealand, without the presumption, the application of general rules on burden of proof is that positive proof of such intention is required for commercial agreement to be enforceable.

In practice, however, under English law, because the presumptions of intention are rebuttable by evidence to the contrary, the parties will try their best to produce evidence to rebut or to reinforce the presumptions, which to a large extent results in the English approach closer to the all-things-considered approach taken by Australia/New Zealand. The key difference lies in that the presumptions only shift the onus of proof in cases where commercial agreements are involved. The effect is that for most commercial cases, the outcome would be the same. Only in (commercial) borderline cases, where neither the plaintiff nor the defendant can prove the parties' intention to be bound or otherwise, the outcome will be different: under the English law there will be a contract by virtue of the presumption, whereas under the Australia/New Zealand law there will not.

To sum up, commercial agreements are prima facie enforceable under current English law and the United States' law, whereas they are not under the current Australian/New Zealand law. Partially based on Klass's observation (Klass, 2009: p. 1468), the current positions of law in these common law jurisdictions regarding the requirement of intention to create legal relations can be summarized as a table below (Table 1), which may be oversimplified, but still be helpful in the discussion of possible law reform options.

Notably, in all these jurisdictions, the practical effect is that domestic/social agreements are presumed unenforceable as a default. It should also be noted that consideration is still required for an enforceable contract in all of these jurisdictions, which means that the intention to create legal relations, where required (such as the situations where domestic/social agreements are involved), is a separate requirement additional to the consideration requirement for an enforceable contract.

\section{Contract Law Reform: A Conservative Approach in the Modern Global Era}

Gulati (2011) proposes to abandon the intention to create legal relations requirement in common law jurisdictions where consideration is required for an enforceable contract, but to keep the intention requirement in jurisdictions where consideration is not required (e.g. in civil law jurisdictions). This paper argues that this may not be a good law reform option. First, this proposal is based on the argument that the existence of consideration is sufficient to prove intention to create legal relations. As this paper argues in Part II A, consideration is neither necessary nor sufficient for the proving of intention to create legal relations.

Second, Gulati's proposal is contrary to the trend of globalisation and the goals of harmonisation and unification of contract law. Contract law concerns about transactions and in such a globalisation era transactions go easily beyond the border of a particular jurisdiction. Surely contract law differences may be 
Table 1.

Comparison of current positions of US, UK and Australia/New Zealand.

\begin{tabular}{ccc}
\hline Jurisdiction & Commercial agreements & Non-commercial agreements \\
\hline US & Enforceable unless intention not to be legally bound manifested & Unenforceable unless intention to be bound proved \\
UK (England) & Enforceable unless intention not to be legally bound strongly proved & Unenforceable unless intention to be bound proved \\
Australia \& New Zealand & Unenforceable unless intention to be legally bound proved & Unenforceable unless intention to be bound proved \\
\hline
\end{tabular}

deal with by private international law rules especially by the parties' choice of the governing law of the contract, but the efficiency and consistency from the unification of contract law is still very attractive. Therefore, unification rather than diversification should be an important objective of contract law reform. Intention to create legal relations requirement is a common feature of civil-law systems (see, e.g. The Principles of European Contract Law, art 2:101), whereas consideration is not $^{7}$.

Third, abandoning the intention to create legal relation will not increase any certainty and/or consistency of contract law, but increase the rigidity. As his paper has argued in Part II, the consideration test is unlikely to work any better than the intention test. Consideration is also subject to the manipulation concern. The uncertainty and inconsistency related to the doctrine of consideration has been illustrated by the difficulty of reconciling the judgments in Williams $v$ Roffey Bros \& Nicholls (Contractors) Lt [1990] 1 All ER 512 and Foakes v Beer (1884) 9 App Cas 605, and the intrusion of the doctrine of promissory estoppel. On the other hand, abandoning the intention test will inevitable bring in a rigidity problem, that is, so long as an agreement is supported by consideration, it is enforceable, whether the parties intended to be legally bound or not. Such rigidity ignores that as a matter of fact, there are many agreements that are supported by consideration but the parties do not intended to be legally bound by them.

Fourthly, abandoning the intention test is contrary to most of the theories on the nature of contract, especially, contractual liability as voluntarily assumed liability, freedom of contract (and freedom from contract as a corollary), and etc. It is also contrary to the judicial opinion that intention to create legal relations is "the marrow of contractual relationships" (Chwee Kin Keong v Digilandmall.com Pte Ltd [2004] 2 SLR(R) 594 at [139]).

It is submitted therefore that intention to create a legal relation should be kept as a requirement of an enforceable contract, whether consideration is also required or not. If something must be abolished, then it is consideration rather than the intention to create legal relations.

It is further submitted that the presumptions based on the domestic/social and commercial arrangements should also be kept. As argued in part III, the underlying value distinction between these two categories of agreements remains unchanged. The presumptions provide certainty to some extent and that they are rebuttable by evidence to the contrary provides flexibility. The change of social environment may be reflected in courts' interpretation of evidentiary facts and their weights and the development of the category of domestic/social agreements.

\footnotetext{
${ }^{7}$ As discussed above, the concept of cause does not correspond to the common law concept of consideration but relates more to morality or the order public, the reason for entering into a contract, and motive or object. See Chloros (1968: pp. 145-146).
}

The Australia/New Zealand approach (with the intention requirement but the presumptions displaced) is not a satisfactory law reform choice. First, it has not substantially changed the non-enforcement default status of domestic/social agreements, in that intention to be legally bound is still required to be positively proved in order for the agreements to be enforceable. For this reason, enforcement of domestic agreements has not been made easier, as feminists and/or advocates of gay/lesbian's rights argue for ${ }^{8}$. The result of dumping the presumptions is not an enforcement default of domestic agreement but a non-enforcement default of commercial agreements. The feminists' argument that domestic agreements should not be treated discriminately from commercial agreements is uphold, but their proposal to make domestic agreement generally enforceable without the need of proving intention to create legal relations failed (in order to achieve this goal, merely abandoning the presumptions is not enough but feminists must prove that the intention to create legal relations should not be a requirement for any enforceable agreement whether a domestic agreement or not). The net effect of merely dumping the presumptions is that a) less certainty of enforceability of commercial agreement, b) a higher cost incurred in proving intention for the enforcement of commercial agreements.

A better option of contract law reform concerning the intention to create legal relations requirement is for all the common law jurisdictions to adopt (or go back to) the orthodox (which is also the current) English law position, that is, to keep both the intention to create legal relations requirements, and the two presumptions and the related evidentiary rules. Such a mechanism balances the need of flexibility and certainty. Flexibility can be achieved by the development of the categories that the domestic/social presumption is applicable, by carving out special agreements from the enforcement default), and courts' discretion in accepting and weighing of evidence to rebut or reinforce the presumptions. The presumptions provide for certainty to some extent, in that at least it is well-known that commercial agreements are prima facie enforceable whereas domestic/social agreements are not. This is better than the allthings-considered approach without the presumptions, as the current position of Australia/New Zealand law, which results in less certainty. As the above analytical comparison shows, such a conservative "reform" will not cause substantial changes to the United States' law, as regarding the intention requirement the practical effect of the current United State law is very similar to the current English law. Nor will this "reform" cause significant difficulties for Australia/New Zealand law as their legal positions were just changed recently, and for most cases, whether commercial or domestic/social, the outcome would not be different, whether the rebuttable presumptions or all-thingsconsidered fact based approach is used (Burrows, Finn \& Todd,

\footnotetext{
${ }^{8}$ See, for example, Peter Goodrich, "Friends in high places: Amity and agreement in Alsatia" (2005) International Journal of Law in Context 41.
} 
2012: pp. 175-176). For other common law jurisdictions, such as Singapore, the English position is also their current position. It seems that such a "reform" is a conservative one. Being conservative, however, is unnecessarily inappropriate in the modern era, especially for courts and law. As a New Zealand Chief Justice once mentioned, the "Courts and the very law itself ... are conservative institutions not given to rapid transformation. There is nothing wrong [with the law and Courts being conservative institutions not given to rapid transformation]"'. Stability and consistency should be important considerations when law reform is proposed.

\section{Conclusion}

As contractual liability stems from the parties' voluntary or intentional assumption of obligations, intention to create legal relations is "[t]he marrow of contractual relationships" (Chwee Kin Keong v Digilandmall.com Pte Ltd [2004] 2 SLR(R) 594 at [139]). Intention to create legal relations is necessary for the formation of an enforceable contract. On one hand, consideration (the test of bargain), and the intention required by offer and acceptance (with certainty) could be evidence of the parties' serious intention to be bound somehow, but serious intention is unnecessarily intention to be legally bound. One the other hand, there are many other ways for the parties to prove their intention to create legal relations. Therefore, consideration, as with offer and acceptance, is neither sufficient nor necessary for the proving of intention to create legal relations. The intention to create legal relations should not be abandoned.

It is true that the doctrine of intention to create legal relations is not perfect, but the doctrine of consideration is very much more problematic. The possibility of abolishing the doctrine of consideration, and the possible alternatives have been seriously considered and proposed not only by academics, but also by official law reform reports and courts in some common law jurisdictions. The doctrine of consideration is very unlikely to work any better than the doctrine of intention to create legal relations. If one of the two tests of enforceability must be abandoned, it should be the doctrine of consideration rather than intention to create legal relations.

Although in the modern era, the distinctive underlying value promoted by domestic/social agreements (shared interest of the parties), significantly different from that of commercial agreements (the pursuit of each parties' self-interest), remains unchanged. The presumptions based on the domestic/commercial distinction remain justifiable.

In addition to theoretical consistency, stability, harmonisation and unification of contract law in the modern global era are also important considerations in proposing contract law reform. These, in addition to the findings from the comparison of the related legal rules in some common law jurisdictions, justifies a conservative approach, that is, common law jurisdictions should go back to the orthodox (and current) English rule. The English law, on one hand, requires the intention to create legal relations for an enforceable contract, which makes it look more, than the "black letter" of the United States' law, in line with the position in civil law jurisdictions. One the other hand, by the adoption of the presumptions and other related evidentiary rules, the English rule produces practical effect substantially similar to the

\footnotetext{
${ }^{9}$ See Honourable Sir Thomas Eichelbaum's speech at “Admission of first graduates from the School of Law, University of Waikato”, reported at [1994] NZLJ 254 at 255.
}

United States' rule and properly balances the needs of flexibility and certainty. Such a mechanism is also widely accepted by other common law jurisdictions to date. Such a reform will not cause an earthquake to contract law in almost all common jurisdictions.

A conservative approach, however, does not mean a complete inaction forever. This paper submits that if something must be abandoned from the prerequisites of formation of a contract, the doctrine of consideration may be abandoned by common law, but not in the near future. As argued in Part II of this paper, an offer necessarily contains a promise by the offeror and the offeree's acceptance must also contain a promise in exchange for the offeror's promise; consideration could be evidence of the parties' intention to be bound somehow, which is already required for offer and acceptance; and intention to be legally bound is the fundamental test of enforceability. Abandoning the consideration requirement will not only make contract law more consistent internally within contract law and within the common jurisdictions, but also be desirable for the harmonisation and unification of contract law internationally. Continental law does not have the consideration concept. The problems with the doctrine of consideration and the benefit from abandoning this doctrine have been strongly argued for by prominent scholars, evidenced by judicial opinions in Singapore High Court and Court of Appeal, and proposed by the United Kingdom Law Commission. Taking into account that the civil law concept of "causa" might be (thought) related to the common law concept of consideration, a compromise can be adopted by making the presence of "reciprocity" a weak presumption of the presence of intention to create legal relations, similar to what Koo (2011) proposes. At this stage, however, a “conservative reformer” would better accept Phang JC’s statement in the Singapore Court of Appeal judgment of Gay Choon Ing v Loh Sze Tie Terrence Peter [2009] 2 SLR(R) 332 at [118]:

... the maintenance of the status quo... may well be the most practical solution in as much as it will afford the courts a range of legal options to achieve a just and fair result in the case concerned... [notwithstanding] problems of theoretical coherence [Emphasis in original].

\section{REFERENCES}

Atiyah, P. S. (1986). Essays on contract. Oxford: Clarendon Press.

Benson, P. (2001). The unity of contract law. In P. Benson (Eds.), The theory of contract law: New essays (pp. 118-205). Cambridge: Cambridge University Press. doi:10.1017/CBO9780511570834

Burrow, Finn, \& Todd (2012). Law of contract in New Zealand (4th ed). Wellington: Lexis Nexis.

Chen-Wishart, M. (2009). Consideration and serious intention. Singapore Journal of Legal Studies, 434-456.

Cheshire, G. C., \& Fifoot, C. H. S. (1969). The law of contract (2nd ed.). Sydney: Butterworths.

Chloros, A. G. (1968). The doctrine of consideration and the reform of the law of contract: A comparative analysis (a paper commissioned by the United Kingdom Law Commission). The International and Comparative Law Quarterly, 17, 137-166. doi:10.1093/iclqaj/17.1.137

Coote, B. (1995). Contract-An underview. Wellington: Legal Research Foundation.

Coote, B. (2010). Contract as assumption: Essays on a theme. Oxford: Hart Publishing.

Courmadias, N. (2006). Intention to create legal relations: The end of presumptions? Australia Business Law Review, 34, 175-185. 
Fried, C. (1981). Contract as promise: A theory of contractual obligetion. Cambridge, MA: Harvard University Press.

Gulati, B. (2011). "Intention to create legal relations": A contractual necessity or an illusory concept. Beijing Law Review, 2, 127-133. doi:10.4236/blr.2011.23013

Heffey, P., Paterson, J., \& Robertson, A. (2002). Principles of contract law. NSW: Lawbook.

Hepple, B. A. (1970). Intention to create legal relations. Cambridge Law Journal, 28, 122-137. doi:10.1017/S0008197300011636

Hillman, R. (2000). The limits of behavioral decision theory in legal analysis: The case of liquidated damages. Cornell Law Review, 85, 717-738.

Keyes, M., \& Burns, K. (2002). Contract and the family: Wither intention? Melbourne University Law Review, 26, 577-595.

Kimel, D. (2003). From promise to contract: Towards a liberal theory of contract. Oxford: Hart Publishing.

Klass, G. (2009). Intent to contract. Virginia Law Review, 95, 14371503.

Koo, Z. X. (2011). Envisioning the judicial abolition of the doctrine of consideration in Singapore. Singapore Academy of Law Journal, 23, 463-503.

Lucke, H. K. (1967-1970). The intention to create legal relations. Adelaide Law Review, 3, 419-430.

McKendrick, E. (2003). Contract law: Text, cases, and material. Ox- ford, NY: Oxford University Press.

Poople, J. (2006). Textbook on contract law (8th ed.). NY: Oxford University Press.

Posner, R. (1998). Rational choice, behavioural economics and the law. Stanford Law Review, 50, 1551-1575. doi:10.2307/1229305

Rostain, T. (2000). Education homo economicus: Cautionary notes on the new behavioural law and economics movement. Law and Society Review, 34, 973-1006. doi:10.2307/3115129

Seddon, N. C., \& Ellinghaus, M. P. (1997). Cheshire and Fifoot's law of contract (7th ed.). Sydney: Butterworths.

Smith, S. A. (2004). Contract theory. Oxford: Oxford University Press. Smith, S. A. (2005). Atiyah's introduction to the law of contract. Oxford: Clarendon Press.

Trebilcock, M. J., \& Elliott, S. (2001). The scope and limits of legal paternalism: Altruism and coercion in family financial arrangements. In P. Benson (Ed.), The theory of contract law: New essays (pp. 4586). Cambridge: Cambridge University Press. doi:10.1017/CBO9780511570834.003

Wightman, J. (2000). Intimate relationships, relational contract theory, and the reach of contract. Feminist Legal Studies, 8, 93-131. doi:10.1023/A:1009252419410

Williston, S. (1957). Williston on contracts (3rd ed). New York: Rochester. 